\title{
Türkiye'deki Belediyelerin Mali Sorunları ve Muhtemel Etkiler
}

\author{
Prof. Dr. Ahmet Ulusoy ${ }^{1}$ \\ Dr. Öğr. Üyesi Mustafa Tekdere ${ }^{2 *}$
}

Geliş tarihi: 20.02.2019

Kabul tarihi: 13.03.2019

\section{Atıf bilgisi:}

Uluslararası Bilimsel

Araştırmalar Dergisi (IBAD)

Cilt: $4 \quad$ Sayı: 2

Sayfa: 167-182 Yıl: 2019

Dönem: Yaz

This article was checked by iThenticate. Similarity Index 08\%

${ }^{1}$ Beykent Üniversitesi, Türkiye, ahmetulusov@beykent.edu.tr,

ORCID ID: 0000-0001-8407-2770

${ }^{2}$ Erzincan Binali Yıldırım Üniversitesi, Türkiye, mtekdere@erzincan.edu.tr, ORCID ID: 0000-0002-6570-8072

\footnotetext{
* Sorumlu yazar
}

\section{öz}

Belediyeler kaynakların daha etkin ve verimli kullanımı yoluyla ekonomik büyüme ve kalkınma üzerinde, katılımcılık konusunda sağladığı avantajlarla demokrasi, hesap verebilirlik, mali disiplin ve mali sorumluluk üzerinde oluşacak pozitif birtakım gelişmelerin odak noktası konumuna gelmiş bulunmaktadır. Söz konusu faktörlerle birlikte refah devleti anlayışının gelişmesi, nüfus artışı, kentleşme süreci ve 1980 sonrası süreçte yaygınlaşan yerelleşme, yerinden yönetim, yönetişim ve hizmette yerellik (subsidiarity) olguları, belediyeleri kamusal hizmet arzı sürecinde ön plana çıkarmıştır. Ayrıca ilgili süreçte belediyeler ile merkezi yönetimler arasında gittikçe artan bir sorumluluk paylaşımı yaşanmış, nitelik ve nicelik bakımından belediyelerin üzerindeki kamusal hizmet yükü artış göstermiştir. Artan hizmet yükü sonucu belediyelerin harcama düzeyleri de yükselmiştir. Fakat görev tahsisi konusundaki müspet gelişmeler özellikle öz gelir tahsisi konusunda yaşanmamıs ve genellikle belediyelerin gelirleri, görev ve sorumluluklarına kıyasla yetersiz kalmıştır. Vergilendirme yetkisine sahip olmayan, yeni gelir kaynakları oluşturamayan, mevcut kaynakları etkin kullanamayan ve genel bütçe vergi gelirleri tahsilatından aktarılan paylara aşırı bağımlı olan Türk belediyeleri, etkin ve verimli hizmet birimleri çizgisinden uzaklaşmakta ve mali özerklik sonucu elde edilebilecek olası faydalardan mahrum kalmaktadır. Anlatılanlar kapsamında bu çalışmada, belediyelerin yaşadığı temel mali sorunlar ve bu sorunların neden olduğu muhtemel etkiler incelenmiştir. Daha etkin, verimli ve vatandaş memnuniyetini artıran belediyelere ulaşmak için sorunların acilen çözülmesi gerektiği sonucuna ulaşılmıştır.

Anahtar Kelimeler: Yerel Yönetimler, Belediye, Yönetişim, Mali Sorunlar 
Financial Problems of Municipalities in Turkey and Possible Effects

\author{
Prof. Dr. Ahmet Ulusoy ${ }^{1}$ \\ Asst. Prof. Dr. Mustafa Tekdere ${ }^{2 *}$
}

First received: 20.02 .2019

Accepted: 13.03.2019

\title{
Citation:
}

Journal of the International Scientific Research (IBAD)

Volume: 4 Issue: 2

Pages: 167-182 Year: 2019

Session: Summer

This article was checked by iThenticate. Similarity Index $08 \%$

\author{
${ }^{1}$ Beykent University, Turkey, \\ ahmetulusov@,bevkent.edu.tr. \\ ORCID ID: 0000-0001-8407-2770 \\ ${ }^{2}$ Erzincan Binali Yıldırım University, \\ Turkey, mtekdere@erzincan.edu.tr, \\ ORCID ID: 0000-0002-6570-8072
}

\footnotetext{
* Corresponding Author
}

\begin{abstract}
The municipalities have become the focal point of some positive developments on economic growth and development through more efficient use of resources. In addition, they have come to the fore in terms of democracy, accountability, fiscal discipline and fiscal responsibility with the advantages they provide for participation. The development of welfare state understanding with these factors, population growth, urbanization process and localization, widespread in the post1980 period, decentralization, governance and locality in service, put municipalities in the foreground in the process of public service supply. Moreover, there has been an increasing share of duties between central governments and municipalities. Public service burden on municipalities increased in quality and quantity. As a result of the increased service burden, the spending levels of municipalities have also increased. However, the positive developments in the allocation of duties have not been experienced in especially own-revenues allocation and have generally been insufficient compared to the revenues, duties and responsibilities of municipalities. Turkish municipalities, which do not have the authority to tax, create new sources of income, cannot use the available resources effectively and overly dependent on the shares transferred from the general budget tax revenues collection are moving away from being efficient service units and are deprived of the possible benefits that may be obtained by financial autonomy. The context of aforementioned, in this study, the main financial problems of municipalities and possible effects of these problems are examined. It was concluded that the mentioned problems should be solved urgently, to reach municipalities more effective and efficient, increase citizens' satisfaction.
\end{abstract}

Keywords: Local Government, Municipality, Governance, Fiscal Problems 


\section{GİRIŞ}

Belediyeler vatandaşların tercihleri ile tutarlı farklılaştırılmış hizmet arzı sayesinde kaynakların daha etkin ve verimli kullanımını sağlayarak ${ }^{1}$, ekonomik büyüme ve kalkınma üzerinde pozitif birtakım etkiler meydana getirmektedir. Ayrıca yerel siyasete katılım konusunda sağladıkları katkılar nedeniyle demokratikleşme, hesap verebilirlik, saydamlık, mali disiplin ve mali sorumluluk gibi birçok konuda yaşanan olumlu gelişmelerin odak noktası haline gelmiş bulunmaktadır. Bunlara ilave olarak merkezi yönetimin kamusal hizmet sunum sürecinde oluşturduğu bazı yetersizliklerin giderilmesi açısından önemli bir dengeleme fonksiyonu üstlenmektedir. Kamusal hizmet arzı bakımından merkezi yönetimi tamamlayıcı bir işleve sahip olan belediyelerin görev ve sorumlulukları arttıkça, merkezi yönetimin kamusal hizmet sunum konusundaki rolü azalmakta ve merkezi yönetim daha makro plan ve programlara yoğunlaşabilmektedir. Ayrıca belediyeler sayesinde yerel düzeyde piyasa benzeri bir rekabet ortamının oluşması ve kamusal hizmet arzında yenilikçi yöntemlerin denenmesi gibi birçok gelişmenin altyapısı oluşturulmaktadır.

Belediyeler yerel yönetim birimleri arasında kilit taşı niteliğinde bir yere sahiptir (Nadaroğlu, 2001: s. 263). Bu nedenle Türkiye'de yerel yönetimler denildiğinde akla ilk gelen birim veya en önemli yerel yönetim birimi, belediyelerdir (Yakar ve Gündüz, 2014, s. 118). Yerindelik ruhunun şehrin yapısına adapte edilmesinde belediyelerin harcama, gelir ve nüfus potansiyeli nedeniyle en etkin birimler olacağ kabul edilmektedir (Alkan, 2005, s. 283, Çetinkaya ve Demirbaş, 2010, s. 2). Çünkü toplam nüfusunun büyük kısmı (2017 yılı verilerine göre \%94.03) belediye (özellikle büyükşehir belediyeleri) sınırları kapsamında yaşamaktadır (TÜIK, 2019). Yerel yönetim harcamalarının (2017 yılı itibariyle toplam yerel yönetim harcamalarının yaklaşık \%75'i) yine önemli bir kısmı belediyelerin egemenliği altında gerçekleşmektedir (Muhasebat Genel Müdürlüğü, 2019).

Belediye hizmetleri devletle halkın birbirine en yakın olduğu hizmetlerdir. Halk devleti daha çok belediye hizmetleri ile tanır. Bu hizmetlere önem verildiğinde halk nazarındaki itibar artar ve halk ile idare birbirine yakınlaşır (Baltacı, 2005, s. 92). Bu bakış açısı yerel düzeydeki sorunların çözümü konusunda da belediyeleri ön plana çıkarmaktadır. Nitekim kentleşme olgusu sonucu, hızla artan nüfusun ve boyutları sürekli büyüyen mekânların ihtiyaçlarının karşılanmasını sağlamak, büyümeyi yönetmek, yönlendirmek ve denetlemek gibi sorumluluklar ile daha geniş alana ve daha çok insana

\footnotetext{
${ }^{1}$ Yerelleşme teorisinin rasyonalitesini oluşturan belli başlı görüşler vardır. Bu görüşler aslında devletin üstlendiği dört temel fonksiyondan biri olan kaynak tahsisi fonksiyonu çerçevesinde yerel birimlerin daha başarılı olduğu temel savından faydalanmaktadır. Yerel yönetimlerin kalan diğer fonksiyonları (dağıtım, istikrar ve düzenleme) ele almada çeşitli gerekçelerle başarısız olacağı kabulü, bu fonksiyonların yönetiminde merkezi yönetimleri ön plana çıkarmaktadır (Bailey, 1999, s. 6-12; Oates, 1999, s. 1121). Musgrave (2004, s. 3-22) ve Musgrave ve Musgrave (1994: 6-14) göre "Kamu Sektörünün Üçlü Tahsis Teorisi" çerçevesinde yerel yönetimler tahsis fonksiyonunu üstlenebilirken, gelir ve servetin yeniden dağılımı ve makroekonomik istikrar fonksiyonunu üstlenmede başarısız olmaktadır. Benzer bir görüş Tiebout ve Musgrave'in "Katlı Kek Modeli" nde de ifade edilmektedir (Oates, 1999, s. 1121-1122; Bülbül, 2013). Oates'in "Yerelleşme Teorisi'nin" özü ise; merkezileşmenin maliyetli bir sistem olduğu temeline dayanmaktadır. Eğer tercihler coğrafi olarak değişiklik gösteriyorsa, merkezi yönetim tarafindan sunulan tek paket halindeki kamusal mal ve hizmetler, bazı yerleşim birimlerinin tercih ettikleri tüketim seviyesinden az veya fazla tüketmelerine neden olabilir. Bu nedenle her mal ve hizmet farklı yönetim kademelerince sunulmalıdır. $\mathrm{Bu}$ sayede hizmet sunum sürecinde farklı tercihlerin göz önüne alınması bakımından nispeten bir avantaj sağlanabilir (marjinal maliyet ve marjinal fayda eşitliği elde edilir). Bu noktada Oates yerel yönetim birimlerini vatandaşlara tercihleri doğrultusunda seçim imkânları tanımaları nedeniyle ön plana çıkarmaktadır (Oates, 1999: 1121-1122, Tanzi, 1996 : 298-299, Faridi vd., 2012: 358-359). Tiebout (1956: 418) ise tüketici-seçmenleri kendi kamusal mal tercihlerini en iyi şekilde karşılayacak alanlara toplanan bir toplum olarak değerlendirmektedir. Ayrıca ona göre kamusal malların sunumu konusunda yerel ve merkezi sunum arasında büyük farklılıklar oluşmaktadır. Tüketici-seçmenlerin tercihleri merkezi seviyede ele alındığında hükümet bu tercih kalıplarını ayarlamayı denemektedir. Hâlbuki yerel seviyedeki çeşitli yönetim birimleri söz konusu tercihlere göre harcama ve gelir kalıplarını arttırıp azaltarak kolayca ayarlamalar yapabilmektedir. Bu sayede tüketiciseçmenler kendi tercih kalıplarına uygun biçimde faydalarını maksimize etmek için en elverişli yerel yönetimlere hareket etmektedirler. Bir diğer ifadeyle tüketici-seçmenler faydalarını maksimize etmek için optimal hizmet/vergi paketi sağlayan yerel yönetimlere göç gerçekleştirmekte veya hizmet/vergi paketinden memnun olmadığı yerel yönetimlerden çıkabilmektedir. Böylece kamusal mal ve hizmetlerden elde ettikleri marjinal fayda ile faydalanmaları karşıllğı ödedikleri vergileri, bir diğer ifadeyle maliyetlerini eşitleyebilmektedirler. Nihai olarak bu göç kaynakların etkin tahsisini sağlamaktadır. "Ayakları ile oylama (Voting by feet)" olarak adlandırılan bu teori, yerel kamusal mallarda tercihlerin açıklanması problemine piyasa tipi bir çözüm getirmekte ve refahı artırmaktadır (Bailey, 1999, s. 62; Tanzi, 1996, s. 299; Gruber, 2010, s. 267; Seidman, 2008, s. 253; Dileyici ve Vural, 2006, s. 165).
} 
hizmet sunulması sorunlarının giderilmesi gerekmektedir. Bu konu ise nüfusun büyük çoğunluğunun yaşadığı belediyelere önemli görevler yüklemektedir (Ökmen vd., 2010, s. 397). Bir diğer ifadeyle 1950 sonrası süreçte artan kentleşme eğilimi, yerel yönetim birimleri arasında belediyelerin önemini gün geçtikçe artırmıştır. Bu kapsamda kentleşmenin oluşturduğu problemlerin yerinde analiz edilmesi ve pratik - kalıcı önerilerle çözülmesindeki en büyük görev, yerel yönetimlere ve özellikle belediyelere düşmektedir.

Türkiye'deki belediyeleri daha etkin ve verimli hizmet birimleri çizgisinden uzaklaştıran; vergilendirme yetkisine sahip olmama, vergiler ile vergi dışı öz gelir kaynaklarının yetersizliği, genel bütçe vergi gelirleri tahsilatından aktarılan paylara aşırı bağımlılık, yeni gelir kaynaklarının oluşturulamaması ve mevcut kaynakların etkin kullanılamaması gibi temel mali sorunlar bulunmaktadır. Ulusal sorunların çözümünde ve ulusal kalkınmanın sağlanmasında merkezi yönetimden sonra en önemli sorumlulukları üstlenen belediyelerin, nitelikli hizmet sunarak vatandaş memnuniyetini artırması için gerekli olanak ve kaynaklara sahip olması, mali sorunlarının ise ivedilikle çözülmesi gerekmektedir. Bu doğrultuda çalışmada; belediyelerin temel mali sorunları ve bu sorunların neden olacağı muhtemel etkiler incelenmiş, ilgili sorunların acilen çözülmesi yolunda bir farkındalık oluşturulması amaçlanmıştır.

\section{Türkiye'deki Belediyelerin Temel Sorun Alanları}

Türkiye'de genel olarak yerel yönetimler, yerel yönetimler içerisinde de belediyeler gün geçtikçe önemi artan birimler olarak dikkat çekmektedir. Gelir ve harcama potansiyeli devamlı artış eğilimi gösteren belediyelerin sosyal ve ekonomik kalkınma konusunda üstlendiği fonksiyon, günümüzde daha önemli bir boyut kazanmıştır. Özellikle belediye harcamalarının daha etkin, verimli ve ekonomik biçimde gerçekleştirilmesi sonucu ulaşılacak faydaların maksimize edilme çabası, belediyelerin sorunlarının tespiti ve acil biçimde çözümü gibi sürekli bir motivasyon içinde yer alınmasını zorunlu kılmaktadır. $\mathrm{Bu}$ kapsamda belediyelerin temel sorun alanları (Ulusoy ve Akdemir, 2014, s. 445-453; Parlak ve Ökmen, 2015, s. 323-324; Genç, 2015, s. 280-305; Özer ve Akçakaya, 2014, s. 428-442; Kutlar vd., 2011, s. 202209):

- Görev ve sorumluluk sınırlarının net biçimde belirlenmemesi nedeniyle (hem dikey hem de yatay seviyede) yetki ve hizmet alanında ortaya çıkan çatışma ve çakışmalar.

- Gelir - gider dengesizliği, öz gelir kaynaklarının yetersizliği, mevcut kaynakların etkin ve verimli kullanılamaması, yeni gelir kaynaklarının oluşturulamaması ve vergilendirme yetkisinin olmaması nedeniyle merkezi yönetime siyasi, idari ve mali açıdan bağımlılık duyulması.

- Belediye görev ve gelirleriyle ilgili yasal mevzuatın güncel olmaması, eksikliği, sık sık değiştirilmesi, yeterince anlaşılamaması ve gerektiği gibi uygulanmaması.

- Hemşerilik bilincinin yeterince gelişmemiş olması.

- Teknik ve idari kapasite yetersizliği.

- Temel ve geleneksel belediye hizmetlerinin özelleştirilmesi.

- Katılımı teşvik eden ve demokrasiye işlerlik kazandıran belediye uygulamalarının (kent konseyleri vb.) etkinsizliği.

- Belediyeye bağlı kuruluşların ve belediye iktisadi teşebbüslerinin yönetim ve denetim sorunları.

- Vesayetçi düzenlemeler.

- Merkezi yönetim ile belediyeler arasında veya belediyelerin kendi aralarında var olan koordinasyon eksikliği.

- Güçlü başkan, güçsüz meclis yapılanması.

- Turizm, sanayi, eğitim, sağlık ve tarım gibi kriterler dikkate alınarak farklı belediye sistemleri oluşturulmaması (tek tip belediye modeli).

- Sunulan hizmetlerle ilgili belirli standartların sağlanamaması.

- Belediyelerde e-belediye uygulamalarına yönelik altyapının gelişmemesi.

- Belediyeye ait teşebbüs ve mülklerin etkin değerlendirilememesi.

- Belediye birimlerinde meydana gelen politik yozlaşma, popülist istihdam politikaları ve nitelikli personel istihdam edilememe sorunu.

- Belediye yönetimi ve vizyonunu belirleyen yerel seçimlerde, genel seçim saikleriyle hareket edilmesi. 
- Bu kapsamda belediye başkan adaylarının seçim sürecinde istihdam ve benzeri makro iktisadi sorunları çözeceği teminatında bulunması.

- İmar planlamaları ile ilgili sorunlar ve rant alanlarının oluşması.

- Kamulaştırma sorunları.

- Küçük belediyelerin doğurduğu ölçek sorunu.

- Performans odaklı ve stratejik planlamaya dayalı çalışma sistemlerinin belediye yapısına entegre edilememesi.

- Kentleşme, çevre, ulaşım, kültürel ve tarihi dokunun korunması, atık toplama ve geri dönüşüm, sosyal belediyecilik, içme suyu ve diğer altyapı hizmetleri konusundaki politikaların rasyonel biçimde yürütülememesi, şeklinde ifade edilebilir.

Belirtilen sorunların arasında belki de en önemlisi, ifade edilen diğer sorunların ortaya çıkmasına da zemin hazırlayan temel problem; "öz gelir kaynaklarının yetersizliği, genel bütçe vergi gelirleri tahsilatından aktarılan paylara aşırı bağımlılık, yeni gelir kaynaklarının oluşturulamaması, mevcut kaynakların etkin kullanılamaması ve vergilendirme yetkisinin olmaması" şeklinde belirtilebilecek mali odaklı sorunlardır (Yüksel, 2004). Dolayısıyla belediyelerin mali sorunları azaldıkça, eş zamanlı olarak diğer sorun alanlarında da iyileşmeler yaşanacak ve belediyeler sorumlulukları çerçevesinde daha ideal hizmet birimleri hüviyeti kazanacaklardır. Bu nedenle belediyelerin mali sorunlarını ve bu sorunların doğurduğu muhtemel etkileri incelemekte fayda vardır.

\section{Türkiye'deki Belediyelerin Mali Sorunları ve Muhtemel Etkiler}

Türkiye'de belediyelerin gelirleri konusunda en üst düzey yasal metinde yer alan bir hükmün diğer tüm düzenlemelere esas teşkil etmesi gerektiğini söylemek mümkündür. Bu hüküm; Anayasa'nın 127. maddesinde yer alan "Bu idarelere görevleri ile orantıl gelir kaynakları sağlanır." hükmüdür. Gelir kaynaklarının genel bütçe üzerinden aktarılan tahsilatlarla veya öz gelir artışıla mı olacağı ifade edilmemiştir. Söz konusu eksiklik veya belirsizlik siyasi, idari, ekonomik ve mali birtakım amaç ve endişelerle birleşince belediyelerin kaynak sorunu, genel bütçe vergi gelirleri tahsilatından aktarılan paylarla çözülmeye çalışılmıştır. Gelir yetersizliği, öz gelir oranlarının düşüklüğü, yeni gelir kaynaklarının oluşturulamaması ve mevcut kaynakların etkin kullanılamaması ile birlikte belediyelerin sahip olduğu öz gelirler kapsamında oransal düzenlemeler yapabilme (vergilendirme) yetkisi kaldırılmış ve yalnızca TBMM ile kanuni sınırlar dâhilinde Cumhurbaşkanı (önceki uygulamada Bakanlar Kurulu), yetkili organlar olarak belirlenmiștir ${ }^{2}$. Dolayısıyla belediyelere artan görevleriyle orantılı gelir kaynağı tam olarak sağlanamamakla birlikte, gerçekleştirilen iyileştirmeler genel bütçeden yapılan transferlere odaklı bir yapı kazanmıştır (Ulusoy ve Akdemir, 2010: s. 132, Sevindik, 2011: s. 40, Yüksel, 2003: s. 5253). Bir diğer ifadeyle belediyeler (özellikle büyükşehir belediyeleri) merkezi yönetim tarafından yapılan transferlere aşırı bağımlı hale gelmiş̧tir. Belediyelerin yaşadığı temel mali sorunların birtakım etkileri bulunmaktadır. Bunlar:

Kaynak sorununun en önemli etkisi belediyelerin sorumlu olduğu hizmetlerin etkin ve verimli sunumunu, nitelik ve niceliğini olumsuz etkilemesidir (Ulusoy ve Akdemir, 2013: s. 89, Akdemir, 2011: s. 367). Ayrıca belediyelerin kaynak yönünden merkezi yönetime bağlı olması, onları ekonomik etkinlik öncelikli bir hizmet birimi olmaktan öte, siyasi çıkarlara hizmet eden bir araca dönüştürmekte ve siyasiidari bağımlılığı arttırmaktadır. Bu durumda merkezi yönetimin izin verdiği ve kaynak aktardığı oranda hizmet verebilen bir belediye sistemi (merkezi yönetimin taşra birimi gibi bir yapı) ortaya çıkmaktadır (Yüksel vd., 2010, s. 317; Şahin, 2011, s. 19; Özmen, 2012, s. 175).

Belediyelerin mali açıdan merkezi yönetime bağlı olması, merkezi yönetim nezdinde yaşanacak konjonktürel mali sorunlardan son derece olumsuz etkilenmesine neden olabilmektedir (Yontar ve Dağ, 2014, s. 156; Egeli ve Diril, 2012, s. 35). Örneğin 2009 y1lında küresel kriz nedeniyle elektrik ve hava gazı tüketim vergisi kısa süreliğine merkezi idare geliri haline getirilmiştir. Bu durum mali özerkliği olumsuz etkilemekle birlikte, belediyelerin etkin bir hizmet planlaması yapabilmesi için gelirleri

\footnotetext{
21982 Anayasası'nın 73. maddesi belediyeler açısından bir diğer sorun alanı olarak ifade edilebilir. İlgili maddeye göre belediyelerin vergilendirme yetkisi bulunmamaktadır. Bu durum, belediyelerin sahip olduğu öz gelir kaynaklarının ve mali özerkliğinin sınırlı düzeyde kalmasının temel nedenlerinden biri olarak görülmektedir. Fakat ilgili sorun ayrı bir çalışma konusu olacak kadar kapsamlı olduğu için burada kısaca değinilmiştir.
} 
konusunda öngörüde bulunmasını da engellemektedir (Gündüzöz, 2012, s. 755-75; Çetinkaya ve Demirbaş, 2010, s. 11). Buna ilave olarak merkezi yönetim ile belediye yönetimi farklı siyasi partilerin elinde olduğunda merkezi yönetim, belediyelere transfer edilecek bir fonu bloke edebilmekte, transferi geciktirebilmekte veya miktarını azaltabilmektedir (Nadaroğlu, 2001, s. 60; Topal, 2004, s. 122; Çelik, 2013, s. 24).

Belediyeler hizmet sundukları toplumun sürekli değişen ve artan ihtiyaçlarını karşılayabilmek için yeterli mali kaynağa sahip olamadıkça, borçlanma yoluna gitmekte ve bu durum ülke kredibilitesini olumsuz etkilemektedir. Gelir yetersizliği nedeniyle borçlanan belediyelerin bu borçları zaman zaman silinmekte veya hazine tarafindan üstlenilmektedir. Bu şekilde dolaylı bir kaynak sağlanmış olsa da belediyelerin kötü bir borçlanma alışkanlığı (ahlaki riziko) (Akdemir, 2011, s. 367; Bali, 2006, s. 155) edinmesine neden olan durum, kaynak israfi problemine sebebiyet verebilmekle birlikte belediyeleri öz gelir oluşturma konusunda pasifliğe itmektedir (Şengül, 2014, s. 197). Ayrıca büyük belediyeler küçük belediyelere oranla daha çok borçlandığı için gelişmiş bölge belediyelerinin borçlanma ve daha sonra borçların silinmesi gibi uygulamalarla elde edilen dolaylı kaynaklardan daha fazla yararlandığı söylenebilir (Yüksel, 2003, s. 54). Belediyelerin hizmet önceliklerini ve finansman imkânlarını belirleyememeleri, bu idareleri teknoloji transferi ve büyük finansman gerektiren yatırım projeleri dışında diğer projeler için de borçlanmaya yöneltmektedir (Acar ve Aydın, 2015, s. 27).

Seçmenler genellikle oy verdikleri belediye yönetiminden daha fazla hizmet talep etmekle birlikte daha az mali külfete katlanmak istemektedir. Bu nedenle seçmenler belediyelerin tahakkuk ve tahsilatını yaptığı öz gelir kaynaklarının tahsilatının yapılmaması ${ }^{3}$, düşük veya geç yapılması yönünde bir beklenti içerisinde olmaktadır. Bu isteğe oy kaygısı güden belediye yönetiminin boyun eğmesi ile öz gelirlerde yaşanacak azalış genellikle borçlanmayla kapatılmaktadır. Seçmen üzerinde kısa dönemde borçlanmanın negatif etkisi daha azdır. Fakat uzun vadede borçlanma nedeniyle katlanılan faiz yükü belediye bütçesinin etkin hizmet sunma kabiliyetini azaltmaktadır (Sevinçhan, 2015, s. 50-56; Ökmen ve Koç, 2015, s. 564). Bu durum 6360 sayılı Kanun ile hizmet sunumunda öncü haline gelen belediye birimlerini (özellikle büyükşehir belediyelerini) zor durumda bırakabilmektedir.

2464 sayılı Belediye Gelirleri Kanunu yürürlüğe gireli otuz yıldan fazla bir süre geçmiştir. Fakat bazı vergilerin konusu, kapsamı, mükellefiyeti, istisna ve muafiyetleri ${ }^{4}$ noktasında güncelleme yapılmamıştır. Bu nedenle belediyeler bazı gelir kaynaklarından hala etkin biçimde yararlanamamakta ve öz gelirlerini arttıramamaktadır (Arıkboğa, 2016, s. 292; Bülbül, 2015, s. 20; Şener, 1998, s. 14). Örneğin haberleşme vergisinin mükellefi PTT olarak belirlenmekle birlikte, 406 sayılı Telgraf ve Telefon Kanunu kapsamında mükellefler Türk Telekomünikasyon Anonim Şirketi (Türk Telekom) ve Türkiye Cumhuriyeti Posta İşletmesi Genel Müdürlüğü olarak belirlenmiştir. Oysa aynı veya benzer hizmeti sunan birçok kurum bulunmasına rağmen bu vergiye tabi değildir. Kanunun içeriğindeki telefon kavramından kasit sabit telefondur. Fakat günümüzde cep telefonu, araç telefonu ve telefon yerine geçen tabletler olmak üzere aynı işlevi gören farklı araçlar mevcuttur. Ayrıca haberleşme hizmetlerinin gittikçe mobil telefonlarla yapılması haberleşme vergisinden elde edilebilecek potansiyel geliri azaltmaktadır. Bununla birlikte data ücreti kavramı, internet bağlantısı ücretini de içermesine rağmen günümüzde mobil veya sabit hatlar kapsamında gerçekleşen internet bağlantısı işlemleri üzerinden haberleşme vergisi hesaplanmamaktadır. Ayrıca haberleşme vergisi, özel iletişim vergisi nedeniyle hala çifte vergilendirme konumunu korumaktadır. İlgili gerekçe yüzünden haberleşme vergisi üzerinde ciddi değişiklikler

\footnotetext{
3 Nacar Karabacak (2013, s. 134)'e göre; “öz gelir yaratma arzusunu zayıflatmada çeşitli etkenlerden bahsedilebilir. Örneğin birikmiş vergi borçlarının (emlak, çevre temizlik) veya vergi dışı gelirlerinin tahsilatında çekingen davranma, emlak vergisi gibi temel bir verginin rayiç bedelinin doğru bir şekilde tespitini sağlayamama gibi siyasi kaygılar ve büyükşehir belediyelerinin kendi sınırları içinde toplanan merkezi yönetim vergi gelirlerinden ayrıca pay alması gibi yasal düzenlemeler."

46360 sayılı Kanunun Geçici 1. maddesinin 15. fikrasında vergisel kolaylıklar sağlayan bir geçiş hükmü bulunmaktadır. Köy tüzel kişiliği kaldırılarak mahalleye dönüştürülen yerlerde uygulanacak bu hüküm ile 2014 yılı Mart ayı öncesinde köy statüsünde olan ancak, belediye mücavir alan sınırları içine alınmış ve belediye hizmetleri götürülen ve bu haliyle 2014 yılına kadar vergileri ödeyen köy statüsündeki yerlerden de vergi alınmamaya başlanmıştır. Söz konusu durum düzenlemenin amacına aykırılık teşkil etmektedir. Önceden yerel hizmetlerden yararlanan ve vergilerini ödeyen mükellefler durumlarında herhangi bir değişiklik olmaksızın geçici muafiyet elde etmiş ve belediyeler öz gelir kaybına uğramıştır (Marmara Belediyeler Birliği, 2015, s. 20).
} 
yapılmamakta ve vergi göz ardı edilmeye çalışılmaktadır. Haberleşme vergisinin oranının \%6 iken \%1'e düşürülmesi söz konusu anlayışın bir tezahürüdür. (Bülbül, 2015, s. 26-30; Marmara Belediyeler Birliği, 2015, s. 4; Arıkboğa, 2016: s. 292, Türkiye Belediyeler Birliği, 2017: s. 48). 2464 sayılı Belediye Gelirleri Kanunu'nda elektrik ve hava gazı tüketim vergisi ile ilgili 34,35 ve 37. maddelere bakıldığında belediyelerin hava gazı üzerinden vergi alması gerekmektedir. Oysa günümüzde hava gazı artık gelir getiren bir matrah olma özelliğini kaybetmiştir. Doğalgaz uygulaması ise neredeyse tüm kentlerimizde bulunmaktadır. Fakat kanun kapsamında doğalgaz üzerinden vergi alınamamaktadır. Bununla birlikte LPG de kapsam dışıdır. Ayrıca tellallık harcı işlevini yitirmekle birlikte, eğlence vergisi ile kaynak suları harcında beyan ve ödeme koşulları günümüz koșullarına uygun değildir (Arıkboğa, 2016, s. 292; Marmara Belediyeler Birliği, 2015, s. 4-6; Türkiye Belediyeler Birliği, 2017, s. 49). İşgal harcında mükellefin türü ve işgalin niteliği dikkate alınmadan $\mathrm{m}^{2}$ başına aynı tarife uygulandığı için mükellef grupları arasında adaletsizlikler olmaktadır (Marmara Belediyeler Birliği, 2015, s. 5). Belediyeler tarafından çeşitli kanun hükümlerine göre kesilen para cezalarından gecikme zammı alınmaması, özellikle cezaların geç tahsil edilmesi durumda belediyeleri gelir kaybına uğratmaktadır (Marmara Belediyeler Birliği, 2015, s. 21). Bazı çalışmalarda Emlak Vergisi Kanunu 8. maddede yer alan muafiyet ve istisnaların fazla olduğu ve belediyeleri gelir kaybına uğrattığı da ifade edilmektedir (Marmara Belediyeler Birliği, 2015, s. 19).

Anlatılanlara ilave olarak Belediye Gelirleri Kanunu'nun çıktığ1 1981 yılından günümüze reklam yöntemleri (led ekran, lazer vb.) değişmiştir. Fakat bu yöntemlere uygulanacak tarife konusunda belirsizlik vardır. $\mathrm{Bu}$ durum farklı uygulamalarla birlikte gelir kaybına neden olmaktadır (Marmara Belediyeler Birliği, 2015, s. 5). Ayrıca ilan ve reklam vergisinde büyükşehir belediyeleri ile ilçe belediyeleri arasında yetki karmaşası bulunmaktadır. Ana arterlerde vergi büyükşehir belediyeleri, ilçelerde ilçe belediyeleri tarafindan tahsil edilmektedir. Ancak ana arterlerin belirlenmesi büyükş̧ehir belediyeleri tarafından yapılmakta ve sık sık değişikliğe uğramaktadır. Bu durum ilçe belediyelerini öz gelir kaybına uğratmaktadır (Marmara Belediyeler Birliği, 2015, s. 19). 6306 sayılı Afet Riski Altındaki Alanların Dönüştürülmesi Hakkında Kanun'un 7. maddesinin 9. fikrasında "Bu Kanun uyarınca yapılacak olan işlem, sözleşme, devir ve tesciller ile uygulamalar, noter harcı, tapu harc1, belediyelerce alınan harçlar, damga vergisi, veraset ve intikal vergisi, döner sermaye ücreti ve diğer ücretlerden; kullandırılan krediler sebebiyle lehe alınacak paralar ise banka ve sigorta muameleleri vergisinden müstesnadır." denilmektedir. Bu hüküm uyarınca kentsel dönüşüm alanlarındaki yeni inşaatlardan imar harcı alınamamakta ve belediyeler öz gelirlerini artıramamaktadır.

Belediye vergi gelirlerinin en önemli kısmını oluşturan emlak vergisinde (Can ve Gündüzöz, 2011, s. 24) vergiye tabi matrahlar (vergi değeri) taşınmazın gerçek alım-satım bedelini yansıtmamaktadır. Çünkü vergi değeri belirlenirken asgari değerler düşük tutulmakta ve maliyet esaslı bir yaklaşım izlenmektedir. Tapu ve kadastro harçlarının yüksek olması nedeniyle mükellefler gerçek alım-satım değerini beyan etmemektedir (Öztürk, 2015, s. 64; Marmara Belediyeler Birliği, 2015, s. 18; Güngör, 2015, s. 14). Dolayisıyla emlak değerleri piyasa rayiç bedellerinde belirlenememektedir. Emlak vergisinde belediyelerin tek yetkisi, takdir komisyonuna iştirak etmektir. Ayrıca vergi oranlarının düşük olduğu da dile getirilmektedir (Gündüzöz, 2012, s. 755-758; Toksöz, 2010, s. 102). Belirtilen nedenler kapsamında belediye hizmetlerinden dolayı artan taşınmaz rantları belediyelere kazandırılamamaktadır. Oysa kentleşmenin tüm olumsuzluklarına belediyeler katlanmaktadır. Neticede emlak vergileri gittikçe verimli ve istikrarlı bir gelir kaynağı olma potansiyelini kaybetmektedir (Şener, 1998, s. 12-13; Türkoğlu, 2012, s. 304). Emlak vergisinde vergi matrahının gerçek değeri yansıtmaması sorunu dolaylı olarak harcamalara katılma paylarını da etkilemektedir. Nitekim 2464 sayılı Belediye Gelirleri Kanununun 89. maddesinde "Harcamalara katılma payları bina ve arsalarda vergi değerinin \%2'sini geçemez." denilmektedir. $\mathrm{Bu}$ nedenle harcamalara katılma payı gelirlerinde, emlak vergisi matrahı üzerinden dolaylı bir sınırlama gerçekleşmektedir (Şener, 1998, s. 13-14).

Belediye gelir yapısı çok sayıda fakat verimsiz (emlak vergisi ve çevre temizlik vergisi dışında) vergi ve harçlardan oluşmaktadır. Bununla birlikte özellikle maktu şekilde belirlenen öz gelirler, gelir matrahındaki gelişmelere uyum sağlayamamakta ve zaman içinde (özellikle enflasyon dönemlerinde) önemini yitirmektedir. Bazı kaynaklardan toplanacak vergilerin tahsil maliyetini bile karşılamaması (ayak bağı vergiler) ise belediyelerin bu tür gelirlerden vazgeçmesine neden olmaktadır. Bu nedenle gelirlerin arttırılması bir yana, mevcut gelir kaynaklarından bile feragat edilmek zorunda kalınmaktadır 
(DPT, 1996, s. 126; Yüksel, 2004; Kerimoğlu vd., 2009, s. 81). Ayrıca belediye kararlarına uymayanlara uygulanacak ceza gelirlerinin caydırıcıllğı ve enflasyon karşısında yaşadığı değer kaybı konusunda adım atılmamaktadır (Şener, 1998, s. 14). Oysa yerel kaynaklar etkin kullanıldığında, kamuda kaynak ihtiyacının azalmasına bağlı olarak vergilerin de azalması beklenebilir. Bunun sonucunda ise vatandaş memnuniyeti artar, kamu hizmetlerine olan eleştiriler azalır ve toplumsal destek güçlenebilir (Yüksel vd., 2010, s. 319).

Genel bütçe vergi gelirlerinden aktarılan kaynakların dağıtım esaslarında geçmişe kıyasla iyileşmeler yaşansa da farklılıkları gözeten ek kriterler (gelir kapasitesi farklılıkları, milli gelire katkı, nüfus yoğunluğu, yaşlı nüfus, eğitim çağındaki nüfus, turistik özellikler, mevsimsel özellikler, işsiz sayısı, konut sayısı, sosyal yardıma muhtaç kişi sayısı, göçmen sayısı vb.) hala getirilemediğinden ve pay oranlarında merkezi yönetim tarafindan zaman zaman tek taraflı değişiklikler yapıldığından dağıtım mekanizması istikrarsız bir görünüm arz edip, ihtiyaçları tam olarak karşılamamaktadır (Ulusoy ve Akdemir, 2009, s. 278-282; Kaplanhan ve Korkut, 2014, s. 3; Marmara Belediyeler Birliği, 2015, s. 26). Buna ilave olarak 5779 sayılı Kanunun 7. maddesinin 2. fikrasına göre genel bütçe vergi gelirlerinden belediyelere İller Bankası aracılığı ile pay aktarımı yapılırken çeşitli kanunlar kapsamında "Aydınlatma Gideri Kesintisi", "Kalkınma Ajansı Payı" ve "İller Bankası Ortalık Payı" gibi kesintiler yapılmaktadır. Türkiye'de genel bütçe vergi gelirleri payının belediyeler için önemli bir gelir kaynağı olduğu açıktır. Bu paydan belediyeler bilgilendirilmeden çok sayıda kesinti yapılması (özelikle anlaşma sağlanmamış borçlar için), belediyelerin gelir kaybına ve mağduriyetine yol açmaktadır (Marmara Belediyeler Birliği, 2015, s. 21-22; Türkiye Belediyeler Birliği, 2017, s. 45-46). Ayrıca 6360 sayılı Kanun ile büyükşehir ilçe belediyelerinin genel bütçe vergi gelirlerinden aldıkları paydan $(\% 4,50) \% 30$ oranında büyükșehir belediyesine, \%10 oranında su ve kanalizasyon idarelerine pay ayrılmaktadır. Bu durum daha önce İller Bankası payını doğrudan alan, ancak büyükşehir ilçe belediyesi olduktan sonra büyükşehir belediyesi ve su kanalizasyon idarelerine pay ayırmak ve kendilerine bağlanan köy nüfusuna da hizmet sunmak durumunda olan ilçe belediyelerini pek olumlu etkilememiş̧ir. Ayrıca büyükşehir belediyelerinin gelirleri artırılsa da İl Özel İdareleri'nin kaldırılması ve büyükşehir belediyelerine yeni sorumlulukların verilmesi gibi nedenlerle gelir-gider dengesi açısından ciddi bir iyileşme beklenmemektedir (Marmara Belediyeler Birlĭgi, 2015, s. 25).

Belediyeler vergilendirme yetkisine sahip olmaması nedeniyle öz gelirler üzerinde matrah, oran ve tarife açısından tasarrufta bulunamamakta ve yine merkezi yönetimin ilgili konulardaki kararlarına muhtaç kalmaktadır ${ }^{5}$. Fakat merkezi yönetimin bu konudaki kararlarının yerel koşullara ve belediyelerin ayrı ayrı ihtiyaçlarına ne derece uyum sağlayacağı tartışmalıdır. Bu nedenle vergi ve harç tarifeleri etkin biçimde güncellenememekte ve belediye gelirleri zamanla önemini kaybetmektedir (Gündüzöz, 2012, s. 755-758; Güngör, 2015, s. 17-18). Örneğin emlak vergisi ve çevre temizlik vergisi dışında vergi ve harç tarifeleri 1992 ve 2004 yıllarında güncellenmekle birlikte, 2004 y1lından günümüze kadar güncellenememiştir (Marmara Belediyeler Birliği, 2015, s. 6; Çetinkaya ve Demirbaş, 2010, s. 12). Anayasa Mahkemesi'nin belediyelerin bazı vergi ve harç tarifelerini belirleme yetkilerini iptal etmesinin ardından kısa sürede üç farklı düzenleme yapılmış ve belediyeler uygulama konusunda bir belirsizlik ve istikrarsılık içine düşmüş, sürekli farklı tarifelerle karşılaşan belediyelerin vatandaş bazında güvenilirliği zedelenmiştir. Yeni tarifelerin belirlenmemiş olması ve ne zaman belirleneceğinin belirsizliği de belediyeler için bugün halen istikrarsızlık kaynağı olmaya devam etmektedir (Marmara Belediyeler Birliği, 2015, s. 12-13; Arıkboğa, 2016, s. 293). Anlatılanlara ilave olarak verimsiz gelir kaynakları fiyat ve gelir hareketliliğine karş1 gittikçe duyarsız hale gelmektedir (Gündüzöz, 2012, s. 901). Gelirlerin esnek bir yapıya sahip olmamasına neden olan bu durum, belediyelerin yerel ihtiyaçları daha çabuk ve etkin bir şekilde karşılama potansiyelini azaltmakta ve kaynaklarını ihtiyaçlarına göre ayarlamalarını engellemektedir (Güner, 2006, s. 80; Arıkboğa, 2015, s. 10). Ayrıca belediyeler nitelikli elemanlarının bulunmaması, teknoloji altyapısının yetersizliği ve yapılan mali uygulamalarda politik kaygıların egemen olması gibi

\footnotetext{
Mesela küçük bir yerleşim yerinde bir ağacın gövdesine çakılmış reklam unsurundan, belediyenin hangi kanuni sınırdan vergi alacağı konusu ya da mahalle arasında kaldırımı işgal eden dükkândan hangi kanuni sınırda işgal harcı alınacağı konusu, yerel yönetimlerin yetki alanında olması gereken hususlardır. Merkezi idarenin bu hususlarla uğraşması gereksiz biçimde üzerindeki yükü arttırmakta ve ilgili konularda tüm çeşitliliği ve dinamizmi kucaklayacak çözümler üretmesini engellemektedir (Arıkboğa, 2014, s. 42).
} 
sorunlar yüzünden, vergilendirme konusunda yetki verilmesi gibi önemli bir süreci hala üstlenememektedir (Dulupçu vd., 2014, s. 42-44).

Vesayet ve mali bağımlılık nedeniyle belediyeler kendi önceliklerine göre harcama yapamamakta ve takdir yetkisini kullanamamaktadır (Yüksel, 2004). Özellikle düşük nüfuslu ve gelişmemiş kentlerdeki belediyelerin öz gelirleri cari giderlerini bile karşılayamamakta ve bu belediyelerde ileri teknoloji ve uzmanlık gerektiren yatırım harcamaları ile sosyal harcamaların boyutu çok yetersiz düzeylerde kalmaktadır (Kaplanhan ve Korkut, 2014, s. 6; Yüksel, 2003, s. 57). Gelir ve kaynak kısitları nedeniyle e-belediye uygulamaları için gerekli altyapı sağlanamamakta ve bu uygulamalar genişletilememekte, kent konseyleri gibi birimlere yeteri kadar kaynak ayrılamadığı için demokratik mekanizmalar işlevsiz kalmaktadır. Örneğin TAKBİS ${ }^{6}$, MERNIS ve POLNET gibi yazılımlar kullanılamadığı ya da eksik kullanıldığı için sürekli yazışma trafiği hem belediyeler hem de ilgili kurumlar için kaynak israfına (zaman, emek, para) ve belediye alacaklarının tahsilatı ve takibi işlemlerinin gecikmesine neden olmaktadır (Marmara Belediyeler Birliği, 2015, s. 14). Belediyeler 6183 sayılı Kanun'un 62. ve 79. maddeleri ve Tahsilat Genel Tebliği'nin ilgili maddeleri kapsamında vergi dairelerinin mal varlığı araştırmalarını ve haciz yapmalarını kolaylaştırmak amacıyla kullandığı e-haciz sisteminden faydalanamamaktadır. Bu nedenle genellikle 10.000 TL'nin altındaki borçların haczini (banka genel müdürlükleri ile yazışmalar yapılamadığı için) gerçekleştirememektedir (Marmara Belediyeler Birliği, 2015, s. 15).

Yerel mali reform çabaları (5779 sayılı Kanunda olduğu gibi) genel bütçeden daha fazla pay vermek olarak algılandığı için belediyelerin öz gelirlerinin arttırılması konusunda ciddi adımlar atılamamakta veya bu yöndeki çalışmalar dizginlenmektedir (Ulusoy ve Akdemir, 2014, s. 450; Ulusoy ve Akdemir, 2010, s. 133; Çalcalı, 2018, s. 477). Mali kapasiteyi arttırma çabasını dikkate almayan yönetimler arası transfer sistemi etkin olmayan, verimsiz ve adaletsiz sonuçlar oluşturabilmektedir (Yılmaz ve Beriş, 2006, s. 96; Arıkboğa, 2016, s. 294). Ayrıca merkezden yapılan transferleri elde etmek için hiçbir çaba harcamayan belediyelerin, kaynakları etkin kullanma gibi bir motivasyonları da bulunmamaktadır (Ökmen ve Koç, 2015, s. 563). Merkezi transferlere bağımlı gelir yapısı ve öz gelirlerin düşüklüğü, bütçe tahminlerinin gerçekçi yapılabilmesini ve katılımcı bütçe çalışmalarını olumsuz etkilemektedir (Arıkboğa, 2015, s. 10; Gündüzöz, 2012, s. 757-758).

Belediyelerin mali kaynaklarının öz gelir odaklı olmaması ve ağırlıklı olarak merkezi transferlere dayanması, hemşerilerin bu idarelere karşı duyarlılıklarını, sorumluluk duygularını ve katılımını olumsuz etkilemektedir ${ }^{7}$. Bu nedenle belediye harcama ve hizmetleri üzerindeki demokratik denetim mekanizmaları akim kalmaktadır (Özer ve Akçakaya, 2014, s. 435; Topal, 2004, s. 122; Ökmen ve Koç, 2015, s. 563). Demokratik denetim mekanizmaları gelişmeyince belediyelerin hesap verebilirliği ve saydamlığı konusundaki tartışmalar artmakta ve belediyeler rant devşirme kapısı olarak görülüp yerel elitlerin temel ilgi alanı haline gelebilmektedir.

Gelirlerin yetersizliği ve gelir konusunda merkezi yönetime olan bağl1lık, hizmetlerin finansmanında bütçe dışı uygulamalara başvurma, hizmetlerin merkezileşmesi (Egeli ve Diril, 2012, s. 28; Tortop, 2008, s. 13; Özer, 2015, s. 534) veya özelleştirme ile hizmet sorumluluğundan kurtulma çabalarının gelişmesi gibi sorunlara neden olabilmektedir. Ayrıca belediyelerin teknik, donanımsal ve idari kapasitesi gelir yetersizliği nedeniyle gelişememekte ve belediyeler iş makinesi gibi temel araçların edinilmesinde bile merkezi yönetimin ayni ve nakdi yardımlarına ihtiyaç duymaktadır. Bir diğer ifadeyle belediyelerin kurumsal yapısı güçlenememektedir (Yayman, 2013, s. 13).

Gelirlerin yetersizliği ve gelir kapasitesindeki farkl1lıklar ülke düzeyinde hizmet bütünlügünün sağlanmasına engel olmakta ve belediyeler, merkezi yönetim tarafından yapılan eşitsizliği giderici yardımlarla bu sorunu kısmen gidermeye çalışmaktadır. Ayrıca öz gelir yetersizliği nedeniyle belediyeler doğrudan veya dolaylı olarak ticari faaliyetlere yönelip gelir elde etme çabası içine girebilmektedir

\footnotetext{
${ }^{6}$ TAKBİS sisteminin ülke genelinde yaygınlaşması halinde, yerel yönetimlerin kent bilgi sistemi kurma çalışmaları daha aktif biçimde işleyebilecektir. Ayrıca belediyelerin en önemli vergi geliri kaynağı olan emlak vergisi ile çevre temizlik vergisi daha sağlıklı biçimde takip ve tahsil edilecek, devletin yaşadığı kayıp-kaçak oranı ise azaltılabilecektir (TAKBİS, 2019).

7 Çevre ve temizlik için vergi alınması ve verginin belediyeler tarafından toplanması sonucu, vatandaşlar çöplerin toplanması ile ilgili talepte bulunmaya başlamışlar, artan hesap sorma sorumluluğu temizlik hizmetlerinin etkinliğini arttırmış ve kentlerimiz daha temiz bir ortama kavuşmuştur (Toksöz vd., 2010, s. 86).
} 
(Toksöz, 2010, s. 102). Bu durum belediyeleri hizmetlerin niteliği veya niceliğinden öte finansına odaklanan bir birime dönüştürmekte ve harcama verimliliği ikinci planda kalabilmektedir. Gelir yetersizliği ile birlikte gelirlerin büyük kısmının (personel, mal ve hizmet alım harcamaları) cari harcamalara ayrılması, belediyelerin prim ve teşvik gibi uygulamalar ile performans odaklı çalışmaları teşvik etme gücünü kısıtlamakta ve daha etkin hizmet sunum süreçleri işletilememektedir. Belediyeler gelir yetersizliği ve merkezi yönetim transferleri ile yardımlarına bağımlı gelir yapısı şeklindeki çıkmaz içerisinde kaldıkça, aşırı merkezileşmenin olumsuz sonuçlarını elimine etme gücünü kaybetmekte, yenilikçi uygulamaların odak noktası haline gelememekte ve vatandaşların istek ve sorunlarını ayrıntılı biçimde ele alarak onların taleplerine uygun hizmet sunma potansiyelini geliştirememektedir. Ayrıca merkezden yapılan toptan/genel yardımlar, aynı miktarda yardıma denk gelecek ve harcanabilir geliri artıracak merkezi bir vergi kesintisinden (ortanca seçmen nezdinde) daha fazla yerel harcamalarda artış etkisi yapmaktadır. Buna sinek kâğıdı etkisi (flypaper effect) denmektedir (Bailey, 1999, s. 233; Bülbül, 2013). Ülkemizdeki mevcut yerel gelir yapısının bu etkiyi tetikleyeceği açıktır. Belediyelere yapılan yardımların siyasi amaçlarla yapılması ve proje finansmanına yönelik şartlı yardımlar ise, idari ve mali vesayete neden olmaktadır (Şener, 1998, s. 15; Türkoğlu, 2012, s. 302; Yüksel, 2003, s. 55). Ayrıca yardımların zaman ve miktarının belli olmaması, belediyelerin mali planlama yapmasını engellemektedir (Ulusoy ve Akdemir, 2009, s. 278). Belediyelerin özellikle vergilerden elde edeceği gelirler harcamalarını finanse etmede çok yetersiz kaldığı için bu yönetimler, genellikle üzerinde tasarruf hakkının olduğu bazı gelirlere zam yaparak aşırı yüklenebilmekte ve o yörede yaşayan kişiler üzerindeki mali yük artarak, kent yaşamı pahalı hale gelebilmektedir (Keleş, 2009, s. 347).

Görüldüğü üzere belediyelerin yaşadığı mali sorunların birçok olumsuz etkisi mevcuttur. Aslında merkezi yönetimin mali bakımdan sıkıntı içinde olması, yerel nitelikli kaynakların da merkezileşmesi sonucunu doğurmuş ve Anayasa'nın 127. maddesindeki hüküm işlevsiz hale gelmiştir. Merkezi transferlere dayalı bir sistemle hükmün içeriği kısmen yerine getirilmeye çalışılmıştır (Yakar ve Gündüz, 2014, s. 132; Topal, 2004, s. 120; Çevikbaş, 2009, s. 10). Özellikle 2000'li y1llar ve sonrasında önemli görevler tahsis edilen belediyelerin öz gelirlerini arttırıcı düzenlemeler henüz yapılmamıştır. Yapılan mali iyileştirme veya reformlarda ise genel bütçeden daha fazla pay verme üzerine odaklanan yanlış politikalar izlenmiş ve bu yöntem temel finansman kaynağı olarak görülmeye başlanmıştır. Bir diğer ifadeyle yerelin merkez eliyle kalkındırılması politikası benimsenmiştir (Yontar ve Dağ, 2014, s. 160; Siverekli ve Duman, 2015, s. 34-36; Yüksel, 2003, s. 56). Bu nedenle belediyeler merkezi yönetim tarafından yapılan transferlere, bağış ve yardımlara son derece bağımlı hale gelerek (Ulusoy ve Akdemir, 2014, s. 450) mali özerklik açısından ciddi eleştirilere maruz kalmıştır.

\section{SONUÇ}

-Daha etkin, verimli ve nitelikli hizmet sunan,

-Kamusal hizmet üretim süreçlerini idari ve mali açıdan daha bağımsız biçimde yürütebilen,

-Yerel önceliklerle/koşullarla tutarlı ve vatandaş tercihlerine göre farklılaştırılmış hizmet sunum süreçleri işletebilen,

-Merkezi düzeydeki mali sorunlardan minimum düzeyde etkilenen,

-Gelirler hakkında daha doğru tahminde bulunarak gerçekçi bütçeler düzenleyebilen, etkin hizmet planlaması yapabilen ve katılımcı bütçe süreçleri geliştirebilen,

-Borç-faiz sarmalına yakalanmayan ve dolayısıyla etkin hizmet sunma potansiyelini kaybetmemiş bütçelerle faaliyetlerini gerçekleştiren,

-Bütçe içerisindeki yatırım harcamaları ile sosyal harcama oranı yüksek,

-Öz gelir oluşturma, öz gelirleri tahsil etme ve kaynakları etkin kullanma konusunda sürekli bir motivasyon içinde olan ve ilgili konularda popülist yaklaşımlar sergilemeyen,

-Kaynakları enflasyon gibi olgular karşısında değer kaybına uğramayan,

-Merkezden yapılan transferlerin ihtiyaçları tam olarak karşıladığı,

-Kent konseyi gibi mekanizmaları aktif çalışan, demokratik denetim mekanizmaları gelişmiş, e-belediye alanında gerekli dönüşümleri sağlamış,

-Hesap verebilirlik, saydamlık, mali ve siyasi sorumluluk ile katılım konusunda gelişme gösteren,

-Ülke genelindeki hizmet bütünlüğüne katkı sağlayan,

-Kurumsal kapasitesi gelişmiş,

-Prim ve teşvik gibi yöntemlerle performans odaklı çalışma süreçlerini teşvik edebilen, 
-Yerel düzeyde mali aldanma riskini azaltan,

-Bütçe dış1 uygulamalar, merkezileşme veya özelleştirme gibi yöntemlerle özellikle temel belediye hizmetleri konusundaki yükümlülüklerden kurtulmaya çalışmayan ve merkezileşmenin neden olduğu olumsuz sonuçları elimine edebilen belediyelere ulaşmak için ilgili yerel birimlerin mali odaklı sorunları acilen çözülmelidir.

Bununla birlikte belediyelerin temel finansman kaynağı; vergiler ve (vergi dışı) diğer öz gelirler olmalıdır. Gelir yetersizliğinin merkezi transferler ile telafi edilmesi ve bunun sonucunda ortaya çıan muhtemel olumsuz etkiler şeklindeki kısır döngü, toplam gelirler içerisindeki öz gelirlerin ${ }^{8}$ payı artırılarak kırılmalıdır.

Belirtilen amaçlar için öncelikle; belediyelerin vergileri ve (vergi dışı) diğer öz gelirleri takip ve tahsil etme konusundaki yasal, idari, teknik ve donanımsal kapasitesi güçlendirilmeli, kurumsal yapısı sağlamlaştırılmalıdır. Ayrıca gelir takip ve tahsil birimlerindeki personel eğitilerek daha nitelikli hale getirilmelidir. Vergilere ve diğer öz gelirlere ait temel öğelerin tespiti ve güncellenmesi ile takip ve tahsil süreçlerinde, siyasi veya popülist amaçlarla hareket edilmemelidir. Matrah tespitleri objektif ve doğru biçimde gerçekleştirilmeli, gelir tarifeleri maktu değil nispi olmalı ve tarifeler artan oranlı biçimde düzenlenmelidir. Ayrıca tarifeler sürekli olarak ve otomatik şekilde güncellenmelidir. $\mathrm{Bu}$ sayede enflasyon vb. nedenlerle belediye gelirlerinde yaşanan değer kayıpları önlenebilecektir. Belediye hizmetlerinin maliyeti konusunda gerçekçi hesaplamalar yapılmalı, fayda yaklaşımını esas alan finansman yöntemleri ile mükellef uyumu artırılmalı ve mali aldanma engellenmelidir. Vatandaşlık bilinci artırılmalı ve vatandaşa somut biçimde kamusal hizmet geri dönüşü sağlanmalıdır. Gelir paylaşımına veya tahsisine yönelik düzenlemelerde, nüfus kriterini tamamlayıcı ek kriterler getirilmelidir. Kalkınma endeksi, gelir kapasitesi farklılıkları, kişi başı gelir, milli gelire katkı, nüfus yoğunluğu, yaşlı nüfus, eğitim çağındaki nüfus, turistik özellikler, mevsimsel özellikler, işsiz sayısı, konut sayısı, sosyal yardıma muhtaç kiși sayısı, göçmen sayısı ve vergi hasılatına katkı gibi ek kriterler ile belediyeler arasında harcama sorumlulukları açısından yapılacak tarife farklılaştırmalarına derinlik kazandırılmalıdır. Belediyelerin finansman sistemi öz gelirleri artırma güdüsünü azaltmamalıdır. Ayrıca belediyelerin finansal yapısını transferler ile güçlendirme anlayışından vazgeçilmelidir. Özellikle görev ve gelir tahsisi arasında tutarlılık olmasına özen gösterilmelidir.

Anlatılanlar çerçevesinde 1982 Anayasası'nın 73. maddesinde değişikliğe gidilerek belediye meclislerine öz gelir kaynakları üzerinde vergilendirme yetkisi hakkı tanınmalıdır. Bu hakkın hazırlık aşaması olarak belediyelere, merkezi yönetim tarafindan belirlenen limitler kapsamında oranları düzenleme yetkisi verilmelidir. İlgili süreçte bölgelerarası dengesizliklerin artmaması ve makro ekonomik istikrarsızlıkların oluşmaması amacıyla tedbirler alınmalıdır. Bununla birlikte yerel ve merkezi yönetimlere birbirini tamamlayıcı unsurlar olarak bakılmalıdır. Yerel düzeyde kayıt dışılıkla mücadele edilmeli, demokratik katılım ve denetim mekanizmaları güçlendirilmelidir. Belediyelerin hizmet sunumunda gösterdiği etkinliği gelir yönetiminde de göstereceği mali bir dönüșüme yönelik kamuoyu hazırlanmalıdır. Dönüşüm sürecinde, belediyelerle ilgili neredeyse her mali düzenlemede karşılaşılan üniter yapının bozulacağı konusundaki endişelerin giderilmesine yönelik adımlar atılmalıdır. Son olarak, öz gelirlere odaklı iyileşmeler gerçekleştirilirken harcamaların etkinleştirilmesi konusu göz ardı edilmemelidir. Vatandaşların talepleriyle ve yerel önceliklerle tutarlı maliyet-etkin hizmet üretimi için politikalar uygulanmalidir.

Bilgilendirme / Acknowledgement: Bu çalışma yazarın Karadeniz Teknik Üniversitesi, Sosyal Bilimler Enstitüsü, Maliye Anabilim Dalında kabul edilen 'Yerel Vergi Sistemlerinin Karşılaştırmalı Analizi: Türkiye'deki Belediyelerin Finansmanı Açısından Bir Model Önerisi" başlıklı doktora tez çalışmasından türetilmiştir.

\footnotetext{
${ }^{8}$ Öz gelirler, yerel yönetimlerin genel bütçe vergi gelirlerinden aldığı paylar, yurtdıșı ve yurtiçi kurum, kuruluş ve kișilerden alınan her türlü yardım, bağışlar ve borçlanma dışında kalan diğer tüm gelirleri olarak tanımlanabilir (MİGM, 2015: 116). Öz gelirler belediyelerin toplanması, muhasebeleştirilmesi, bütçeleştirilmesi ve harcanmasında tamamen kontrol sahibi olduğu gelirlerdir (Yılmaz vd., 2012, s. 239; Kerimoğlu vd., 2009, s. 79; Arıkboğa, 2016, s. 278).
} 


\section{KAYNAKÇA}

Acar, F. ve Aydın, F. (2015). Tüm yönleri ile belediye gelirleri. Güncellenmiş 2. Baskı. Ankara: TBB, 18 Ağustos $2016 \quad$ tarihinde http://www.tbb.gov.tr/online/yayinlar/tum_yonleri_ile_belediye_gelirleri/files/web\%20belediye \%20gelirleri.pdf adresinden erişildi.

Akdemir, T. (2011). Küresel krizin yerel yönetimlerin mali yapılarına etkileri. Küreselleşme ve kamu yönetiminde dönüşüm. (Kesik, A., ve Canpolat, H., ed.). 359-389. 1. Bask1. Ankara: Seçkin Yayınc1lık.

Alkan, A. T. (2005). Şehir ve şehir kavramlarını yeniden yorumlamakta belediyelerin yeni görevleri üzerine düsünceler. İslam geleneğinden günümüze şehir hayatı ve yerel yönetimler, II. (Akyüz, V., ed.). 281-285. İstanbul: İlke Yayıncilik.

Arıkboğa, Ü. (2015). Türkiye'de yerel vergi yönetimi. Maliye Dergisi, (168): 1-19. 10 Kasım 2016 tarihinde https://dergiler.sgb.gov.tr/calismalar/maliye_dergisi/yayinlar/md/168/168-01.pdf adresinden erişildi.

Arıkboğa, Ü. (2016). Türkiye'de belediyelerin gelir yapısı: Sorunlar ve çözüm önerileri. Mustafa Kemal Üniversitesi Sosyal Bilimler Enstitüsü Dergisi, 13(33): 276-297. 10 Temmuz 2017 tarihinde http://dergipark. gov.tr/download/article-file/183470 adresinden erişildi.

Arıkboğa, E. (2014). Belediyelerin vergi oranlarını belirleme yetkisi. Illler ve Belediyeler Dergisi, (795796): 36-42. 10 Kasim 2016 tarihinde http://www.tbb.gov.tr/basin-ve-yayin/yayinlar/dergi/ adresinden erişildi.

Bailey, S. J. (1999). Local government economics: Principles and practice. UK: Macmillan Press Limited.

Bali, B. B. (2006). Mali desentralizasyon sürecinde yerel yönetimlerin borçlanması: Bir teorik çerçeve denemesi. Mali yerelleşme: Teori ve uygulama üzerine yazılar. (Güner, A., ve Y1lmaz, S., ed.). 149-177. 1. Basım. İstanbul: Güncel Yayıncılık.

Baltacı, C. (2005). Dört halife devri şehir hayatı ve yerel yönetim hizmetleri. İslam geleneğinden günümüze şehir hayatı ve yerel yönetimler, I. (Akyüz, V., ed.). 81-103. İstanbul: İlke Yayınc1lı

Bülbül, D. (2013). Türkiye'de yerel yönetimlerin kamu kesimi bütçesi üzerine etkileri. IAAOJ Social Science, 1(2): 48-69. 3 Temmuz 2016 tarihinde http://dergipark.gov.tr/download/articlefile/470271 adresinden erişildi.

Bülbül, D. (2015). Haberleşme vergisinde yaşanan mali sorunlar, Türkiye Belediyeler Birliği. İller ve Belediyeler Dergisi, (807-808): 26-30. 10 Kasim 2016 tarihinde http://www.tbb.gov.tr/basin-veyayin/yayinlar/dergi/ adresinden erişildi.

Can, H. H. ve Gündüzöz, İ. (2011). Türk mahalli idarelerinin mali yapısı: Gelir ve giderlere analitik yaklaşım, borçlanma sistemlerinin AB ülkeleri ile mukayesesi. Ankara:Türkiye Belediyeler Birliği.

Çalcalı, Ö. (2018). Yönetimler arası transferlerin yerel vergileme gayreti üzerine etkisi: Doğu Karadeniz bölge belediyeleri üzerine bir uygulama. Maliye Dergisi, (174). 18 Kasım 2018 tarihinde https://dergiler.sgb.gov.tr/calismalar/maliye_dergisi/yayinlar/md/174/174-21.pdf adresinden erişildi.

Çelik, A. (2013). Yerel özerklik açısından 5393 sayılı belediye kanununun genel bir değerlendirmesi. Süleyman Demirel Üniversitesi IIIBF Dergisi, 18(1): 17-28. 5 Şubat 2016 tarihinde http://dergipark.gov.tr/sduiibfd/issue/20819/222786 adresinden erişildi.

Çetinkaya, Ö. ve Demirbaş, T. (2010). Belediye gelirlerinin analizi ve mali özerklik açısından değerlendirilmesi. İstanbul Üniversitesi, Maliye Araştırma Merkezi Konferansları, 53. Seri, 1-18. 4 Şubat 2016 tarihinde http://dergipark.gov.tr/iumamk/issue/742/8012 adresinden erişildi. 
Çevikbaş, R. (2009). Belediyelerde idari ve mali özerkliğin uygulanmasında ortaya çıkan sorunlar ve çözüm önerileri. Iller ve Belediyeler Dergisi, (738-739). 7 Şubat 2016 tarihinde file:///C:/Users/Samsung/Downloads /iller-ve-belediyeler-dergisi.pdf adresinden erişildi.

Dileyici, D. ve Vural, İ. Y. (2006). İdarelerarast rekabet ve mali yerinden yönetim. Kamu ekonomisi ve kamu politikası. (Aktan, C., Dileyici, D., ve Vural, Y., ed.). 159-178. 2. Baskı. Ankara: Seçkin Yayınc1lı.

DPT (1996). Yedinci beş yıllık kalkınma planı. 15 Ağustos 2016 tarihinde http://www.kalkinma.gov.tr/Lists/Kalknma \%20Planlar/Attachments/3/plan7.pdf adresinden erişildi.

Dulupçu, M. A., Özkul, G., Ünlü, H. ve Sayın, M. (2014). Yerel yönetimlerin vergilendirme yetkisine ilişkin değerlendirme. Süleyman Demirel Üniversitesi Sosyal Bilimler Enstitüsü Dergisi, 2(20): 27 54. 7 Temmuz 2016 tarihinde http://dergipark.gov.tr/download/article-file/215708 adresinden erişildi.

Egeli, H. ve Diril F. (2012). Türkiye'de yerel yönetimlerde mali özerklik ve vergilendirme yetkisi. Saylştay Dergisi, (84): 25-44. 7 Ağustos 2016 tarihinde http://www.acarindex.com/dosyalar/makale/acarindex-14239 11477.pdf adresinden erişildi.

Faridi, M. Z., Chaudhry, M. A. ve Ansari, F. N. (2012). The impact of fiscal decentralization, inequality and poverty on employment: Evidence from Pakistan. Pakistan Journal of Social Sciences, 32(2): 347-369. 2 Temmuz 2016 tarihinde http://www.bzu.edu.pk/PJSS/Vol32No22012/Final_PJSS-322-06.pdf adresinden erişildi.

Genç, F. N. (2015). Belediyelerin temel sorun alanları. İdari ve mali açıdan türkiye'de yerel yönetimler. (Mecek, M., Doğan, M., ve Parlak, B., ed.). 275-310. Antalya: BEKAD Yayınları.

Gruber, J. (2010). Public finance and public policy. Third Edition. USA: Worth Publishers.

Gündüzöz, İ. (2012). Belediye ekonomisi: Belediyelerin ekonomideki yeri ve önemi. Ankara: Türkiye Belediyeler Birliği. 1 Ağustos 2016 tarihinde http://www.tbb.gov.tr/online/yayinlar/belediye_ ekonomisi/ adresinden erişildi.

Güner, A. (2006). Yönetimler arası gelir bölüşümü: Temel ilke ve uygulamalar. Mali yerelleşme: Teori ve uygulama üzerine yazılar. (Güner, A., ve Yılmaz, S., ed.). 61-82. 1. Basım. İstanbul: Güncel Yayıncilık.

Güngör, H. (2015). Belediye öz gelirlerinin tahsilat1 ve denetimi. İller ve Belediyeler Dergisi, (811): 1020. 15 Ağustos 2016 tarihinde http://www.tbb.gov.tr/basin-ve-yayin/yayinlar/dergi/ adresinden erişildi.

Kaplanhan, F. ve Korkut, C. (2014). Merkezi yönetim vergi gelirlerinin yerel yönetimlere dă̆ıtımı: küreyerelleşme. International Conference on Eurasian Economies, 1-9. 4 Ağustos 2016 tarihinde https://www.avekon .org/papers/1127.pdf adresinden erişildi.

Keleş, R. (2009). Yerinden yönetim ve siyaset. Genişletilmiş 6. Basım. İstanbul: Cem Yayınevi.

Kerimoğlu, B., Güngör, H. ve Koyuncu, E. (2009). Belediye bütçesi nasll izlenir? Yerel paydaşlar için rehber. Ankara: TEPAV Yayınları. 5 Temmuz 2016 tarihinde http://www.tepav.org.tr/upload/files/1271241449r7524. Belediye_Butcesi_Nasil_Izlenir.pdf adresinden erişildi.

Kutlar, A., Yüksel, F. ve Bakırcı, F. (2011). Türkiye'de belediyelerin ekonomik etkinliği ve etkinliğe etki eden faktörler üzerine bir araştırma. Ankara: Türkiye Belediyeler Birliği. 7 Ağustos 2016 tarihinde http://www.tbb.gov.tr/online/yayinlar/ekonomik_etkenler/ adresinden erişildi.

Marmara Belediyeler Birliği (2015). Belediyelerin mali sorunları ve çözüm önerileri. Çalıştay Raporu, İstanbul. $\quad 9 \quad$ Ağustos $2016 \quad$ tarihinde http://marmara.gov.tr/UserFiles/Attachments/2017/04/14/7d174b70-19d6-4e93-a8e62559cce259d9.pdf adresinden erişildi. 
MİGM (2015). 2014 yll mahalli idareler genel faaliyet raporu. 9 Ağustos 2016 tarihinde http://www.migm.gov.tr/kurumlar/migm.gov.tr/YAYINLAR/FAAL\%C4\%B0YET\%20RAPORL ARI/2014_Faaliyet_Raporu.PDF adresinden erişildi.

Muhasebat Genel Müdürlügü (2019). Genel Yönetim Bütçe Ístatistikleri. 9 Ağustos 2016 tarihinde https://www.muhasebat.gov.tr/content/genel-yonetim-mali-istatistikleri/genel-yonetim-butceistatistikleri-yeni adresinden erişildi.

Musgrave, Richard A. ve Musgrave, Peggy B. (1994). Public finance in theory and practice. Fifth Edition. USA: McGraw-Hill, International Edition.

Musgrave, R. A. (2004). Kamu maliyesi teorisi. (Şener, O., ve Methibay, Y., çev.). Ankara: Asil Yayın Dağıtım.

Nacar Karabacak, B. (2013). Yerel yönetimlerde esnek bütçe kısıtı: Kavram, ülke deneyimleri ve Türkiye. Sayıştay Dergisi, (90): 119-141. 11 Haziran 2016 tarihinde https://www.sayistay.gov.tr/tr/Upload/ 95906369/files/dergi/pdf/der90m6.pdf adresinden erişildi.

Nadaroğlu, H. (2001). Mahalli idareler: Teorisi-ekonomisi-uygulaması. Yenilenmiş 7. Baskı. İstanbul: Beta Yayınc1lik.

Oates, W. (1999). An essay on fiscal federalism. Journal of Economic Literature, 47: 1120-1149. 9 Ağustos 2016 tarihinde https://www.jstor.org/stable/2564874?seq=1\#page_scan_tab_contents adresinden erişildi.

Ökmen, M., Yılmaz, A. ve Mazı, F. (2010). Kentleşme sürecinde yerel yönetimlerin sosyal sorumluluğu ve çevre. (Parlak, B., ed.). Yerel Yönetimler: Yerel Siyaset ve Kentsel Politikalar, IV. Kamu Yönetimi Sempozyumu Bildiriler Kitabı. 93-414. 1. Bask1. Bursa: Dora Yayıncılık,

Ökmen, M. ve Koç, N. (2015). Türkiye'de belediye gelirleri içinde borçlanma ve borçların azaltılması için öneriler. Yönetim ve Ekonomi, 22(2): 551-565. 5 Mayıs 2016 tarihinde http://dergipark.gov.tr/yonveek/issue/13703/165912 adresinden erişildi.

Özer, M. A. ve Akçakaya, M. (2014). Yerel yönetimler. Ankara: Gazi Kitabevi.

Özer, M. A. (2015). Yerel yönetim merkezi yönetim ilişkilerinde gelir bölüşümü sorunu ve Türkiye'deki son durumun değerlendirilmesi. Türk İdare Dergisi, (481): 525-558. 12 Temmuz 2016 tarihinde http://www.tid.gov.tr/makaleler/yerel\%20y\%C3\%B6netim\%20merkezi\%20y\%C3\%B6netim $\% 20 \%$ C4\%B0li\%C5\%9Fkilerinde $\% 20$ gelir\%20b\%C3\%B61\%C3\%BC\%C5\%9F\%C3\%BCm\%C3 $\%$ BC\%20sorunu\%20ve\%20t\%C3\%BCrkiye'deki\%20son\%20durumun\%20de\%C4\%9Ferlendirilm esi.pdf adresinden erişildi.

Özmen, A. (2012). Osmanlı'dan cumhuriyet'e anayasalarda merkezi yönetim-yerel yönetim ilişkileri. Uluslararası Sosyal ve Ekonomik Bilimler Dergisi, 2(2): 171-175. 12 Temmuz 2016 tarihinde http://dergipark.gov.tr/download/article-file/403193 adresinden erişildi.

Öztürk, S. (2015). Belediyelerde vergi tahsilatı ve sorunları, Türkiye Belediyeler Birliği. Illler ve Belediyeler Dergisi, (807-808): 58-64. 12 Temmuz 2016 tarihinde http://www.tbb.gov.tr/basin-veyayin/yayinlar/dergi/ adresinden erişildi.

Parlak, B. ve Ökmen, M. (2015). Yerel yönetimler. Genişletilmiş, Gözden Geçirilmiş ve Güncellenmiş 4. Baskı. Bursa: Ekin Yayınevi.

Seidman, L. S. (2008). Public finance. McGraw-Hill Series in Public Finance, USA: McGrawHill/Irwin.

Sevinçhan, Y. (2015). Belediyelerin borçlanması, Türkiye Belediyeler Birliği. İller ve Belediyeler Dergisi, (807-808): 48-57. 7 Ağustos 2016 tarihinde http://www.tbb.gov.tr/basin-veyayin/yayinlar/dergi/ adresinden erişildi. 
Sevindik, S. (2011). AB fonlarının belediyelerin mali sorunlarının çözümündeki etkisi. Illler ve Belediyeler Dergisi, (755): 40-43. 7 Ağustos 2016 tarihinde http://www.tbb.gov.tr/basin-veyayin/yayinlar/dergi/ adresinden erişildi.

Siverekli, E. ve Duman, A. K. (2015). Küreselleşme sürecinde yerelleşme ve Türkiye'ye yansımaları: Kapanan belediyelerin borçları erteleniyor. Iller ve Belediyeler Dergisi, (802): 24-36. 7 Ağustos 2016 tarihinde http://www.tbb.gov.tr/basin-ve-yayin/yayinlar/dergi/ adresinden erişildi.

Şahin, Y. (2011). Yeni anayasada Türkiye'nin idari yapısı ve yerinden yönetim ilkesi. Ankara: SDE Analiz.

Şener, M. (1998). Türkiye'de belediyelerin finansman sorunlarl ve çözüm önerileri. 7-24. 7 Ağustos 2016 tarihinde http://cu.dergipark.gov.tr/download/article-file/50033 adresinden erişildi.

Şengül, R. (2014). Yerel yönetimler. 4. Baskı. Kocaeli: Umuttepe Yayınları.

TAKBİS (2019). 7 Ağustos 2016 tarihinde https://www.takbis.com/takbis-nedir.html adresinden erişildi.

Tanzi, V. (1996). Fiscal federalism and decentralization: A review of some efficiency and macroeconomic aspects, annual world bank conference on development economics. The World Bank, 295-315. 2015 Ağustos 2016 tarihinde https://www.mef.gob.pe/contenidos/pol_econ/documentos/Fiscal_ Federalism_Decentralization.pdf adresinden erişildi.

Tiebout, C. (1956). A pure theory of local expenditures. The Journal of Political Economy, 64(5): 416424. $19 \quad$ Nisan 2016 tarihinde http://www.unc.edu/ fbaum/teaching/PLSC541_Fall08/tiebout_1956.pdf adresinden erişildi.

Toksöz, F. (2010). Avrupa Birliği ve Türkiye'de yerel yönetimler. Ankara: Türkiye Belediyeler Birliği. 22 Mart 2016 tarihinde http://projects.sklinternational.se/tuselog/files/2013/07/AVRUPABIRLIGI-VE-TURKIYEDE-YEREL-YONETIM1.pdf adresinden erişildi.

Toksöz, F., Özgür, A. E. ve Koç, L. (2010). Küreselleşme ve yerelleşme bağlamında yerel yönetimler: Türkiye örneği. Türkiye'de yerel yönetimlerin sorunlarl ve geleceği. (Falay, N., Kesik, A., Çak, M., ve Karakaş, M., ed.). 63-92. 2. Baskı. Ankara: Seçkin Yayıncılık.

Topal, A. K. (2004). Belediyelerin öz gelirlerinin arttırılmasında vergilendirme yetkisi: Ülkeler arası bir karşıllaştırma. IIBFF Dergisi, 18(3-4): 119-133. 19 Nisan 2016 tarihinde http://dergipark.gov.tr/download/article-file/29963 adresinden erişildi.

Tortop, N. (2008). Yerel yönetimlerin hizmet ve gelir bölüşümünün önemi ve saydamlık. Illler ve Belediyeler Dergisi, (727): 13-14. 7 Temmuz 2016 tarihinde http://www.tbb.gov.tr/basin-veyayin/yayinlar/dergi/ adresinden erişildi.

TÜİK (2019). https://biruni.tuik.gov.tr

Türkiye Belediyeler Birliği (2017). Faaliyet raporu. 24 Temmuz 2018 tarihinde http://www.tbb.gov.tr/online/faaliyetraporu /2017/html5forpc.html adresinden erişildi.

Türkoğlu, İ. (2012). Belediye gelirleri ve yeni bir gelir kaynağı olarak şehirleşme rantı. Elektronik Sosyal Bilimler Dergisi, 11(40): 293-305. 13 Ağustos 2016 tarihinde http://dergipark.gov.tr/download/article-file/70374 adresinden erişildi.

Ulusoy, A. ve Akdemir, T. (2009). Yerel yönetimler ve mali özerklik: Türkiye ve OECD ülkelerinin karşılaştırmalı analizi. Balıkesir Üniversitesi Sosyal Bilimler Enstitüsü Dergisi, 12(21): 259-287. 14 Ağustos 2016 tarihinde http://sbe.balikesir.edu.tr/dergi/edergi/c12s21/makale/c12s21m17.pdf adresinden erişildi.

Ulusoy, A. ve Akdemir, T. (2010). Yönetimlerarası transferler: Teori ve Türkiye uygulaması. Türkiye'de yerel yönetimlerin sorunlart ve geleceği. (Falay, N., Kesik, A., Çak, M., ve Karakaş, M., ed.). 113142. 2. Bask1. Ankara: Seçkin Yayıncılık. 
Ulusoy, A. ve Akdemir, T. (2013). Yerel yönetimlerin finansman sorunlarının çözümünde motorlu taşıtlar vergisi önerisi. Sosyoekonomi, 2013(1): 87-116. 4 Mart 2018 tarihinde http://sosyoekonomi.dergipark. gov.tr/download /article-file/197743 adresinden erişildi.

Ulusoy, A. ve Akdemir, T. (2014). Mahalli idareler. Güncellenmiş 9. Baskı. Ankara: Seçkin Yayınevi.

Yakar, S. ve Gündüz, İ. O. (2014). Türkiye'de belediyelerin vergilendirme yetkisi: "Var" mı "Yok" mu işte bütün mesele bu. Sayıştay Dergisi, (92): 117-141. 7 Ağustos 2016 tarihinde https://www.sayistay.gov .tr/tr/Upload/95906369/files/dergi/pdf/der92m5.pdf adresinden erişildi.

Yayman, D. (2013). Türkiye'de yerel yönetimlerin mali yapısı. Akademik Bakış Dergisi, (34): 1-18, 21 Haziran 2016 tarihinde https://www.akademikbakis.org/eskisite/34/21.pdf adresinden erişildi.

Yılmaz, S. ve Beriş, Y. (2006). Yönetimlerarası mali transferler: Teorik çerçeve ve Türkiye uygulaması. Mali yerelleşme: Teori ve uygulama üzerine yazllar. (Güner, A., ve Yılmaz, S., ed.). 95-119. 1. Basım. İstanbul: Güncel Yayıncılık.

Yılmaz, H. H., Emil, M. F. ve Kerimoğlu, B. (2012). Yerel Yönetimler Maliyesi - Temel İlkeler ile Mevzuat ve Uygulama Açısından Türk Yerel Yönetim Yapılanmasında Mali Yönetim ve Kaynak Kullanım Sistemi. Ankara: Mali Hizmetler Derneği.

Yontar, İ. G. ve Dă̆, M. (2014). Avrupa yerel yönetimler özerklik şartı çerçevesinde Türkiye'de mali özerklik. Uluslararası Yönetim İktisat ve İsletme Dergisi, 10(21): 147-162. 8 Nisan 2016 tarihinde http://ijmeb.org/index.php/zkesbe/article/view/8 adresinden erişildi.

Yüksel, F. (2003). Belediye gelirlerinde yetersizlikler ve alternatif çözüm önerileri. S. Ü. İIBF Sosyal ve Ekonomik Araştırmalar Dergisi: 49-60. 8 Nisan 2016 tarihinde http://dergipark.gov.tr/download/article-file/289641 adresinden erişildi.

Yüksel, F. (2004). Türkiye'de belediyeciliğin mali sorunları. Mevzuat Dergisi, 7(73). 8 Nisan 2016 tarihinde https://www.mevzuatdergisi.com/2004/01a/04.htm adresinden erişildi.

Yüksel, F., Bakırcı, F. ve Kutlar, A. (2010). Yerel yönetimlerin ekonomik etkinliği ve ilgili faktörler üzerine teorik bir değerlendirme. (Parlak, B., ed.). Yerel Yönetimler: Yerel Siyaset ve Kentsel Politikalar, IV. Kamu Yönetimi Sempozyumu Bildiriler Kitabı. 315-331. 1. Bask1. Bursa: Dora Yayınc1lik. 